\title{
ToxicDocs (www.ToxicDocs.org) goes live: A giant step toward leveling the playing field for efforts to combat toxic exposures
}

\author{
Anthony Robbins ${ }^{1} \cdot$ Phyllis Freeman $^{1}$
}

(C) Macmillan Publishers Ltd., part of Springer Nature 2018

For workers, consumers, and the whole population, toxic exposures constitute an ongoing challenge for public health. Rarely have toxicologic science, information technology, and large collections of information come together to make new public health progress seem so likely. We have invited two members of our Editorial Board, Gerald Markowitz and David Rosner, and their colleague Merlin Chowkwanyun, to tell the story of their project, ToxicDocs, and of the new database, www. ToxicDocs.org.

We publish their Guest Editorial [1] as an introduction to this fabulous new database, to introduce it to readers worldwide. Even though the process by which Rosner and Markowitz encountered the vast majority of these documents is possibly unique to the United States judicial system (so called 'discovery' of internally held documents by parties to a lawsuit that become public in court records), the materials themselves may provide a means for people worldwide to counter injurious industry behavior in their countries.

Thus, together we have sought commentaries from colleagues in various parts of the world and from varied perspectives (journalists and researchers, among others) to begin a discussion of how to broaden use-and the impact of such use-of this powerful new resource for protecting public health. We join the Commentaries together in a collection as the third component in this Special Section. (See the list below.)

But this is just the start. ToxicDocs can add fuel to the efforts of all the community groups around the world who have suspected that the health harms observed in their communities are caused by toxic exposure, but who lack the experts or information to pursue the sources of the toxic agents. These groups increasingly characterize themselves as the environmental justice movement, as more often than not, exposures affect low-income populations and people of color.

Phyllis Freeman

jphp@umb.edu

1 Co-Editors, Journal of Public Health Policy, Boston, MA, USA 
ToxicDocs seems particularly useful to these groups-whose insights are likely to add to and complement those of researchers represented in this Special Section.

Next steps? Because our goal is to broaden awareness and use of www.toxicdocs. org, all three elements of this Special Section will always be free to view and share. Going forward we want the Journal of Public Health Policy to add scope and depth to this discussion.

We invite readers to share this Special Section actively and widely. Send it to your friends and colleagues, post it on your websites, Facebook pages, and tweet about it. We seek contributions about ToxicDocs, its uses, fruits of analyses, and impact. We invite readers to submit Commentaries or Letters to the Editors-and to urge others to do so.

The Commentaries in this Special Section: [2]

1. Stéphane Horel, an investigative journalist for Le Monde in Paris offers a European perspective. With the European Union as the latest epicenter globally for leading-edge environmental and public health regulation, she explains how ToxicDocs generates evidence of organized deceit and much more-evidence that the European legal systems would not produce in the way that the US one has [2].

2. Christer Hogstedt, former Deputy Director General of the Swedish National Institute of Working Life and David Wegman, a specialist in occupational health epidemiology, surveillance, and policy from the US explain how ToxicDocs will be a strong weapon in the fight against biased public health science and corrupt lobbying in the interest of private profit-including in low and middle income countries that may experience later introduction or prolonged use of toxic materials such as pesticides [3].

3. Jock McCulloch describes the ways that ToxicDocs illuminates the impact of the asbestos industry in southern Africa and Australia [4]. He is perhaps the most renowned scholar of the global impact of the asbestos industry. He has recently been involved with lawsuits seeking redress from some of the world's largest and most powerful mining companies for imperiling the health of former gold miners in southern Africa-. Zambia, Botswana, Swaziland, and Malawi all sent workers to South Africa's gold mines.

4. Sheldon Whitehouse is a United States Senator representing Rhode Island. He has been a leading voice in the US Senate and beyond, fighting to break through the barricade of special interests in Washington that block action on climate change. Here he traces his collaboration with Markowitz and Rosner, from an earlier period when he served as Rhode Island Attorney General and as US Attorney there. That collaboration did much to inspire the creation of ToxicDocs [5].

5. Robert N. Proctor, an historian of science at Stanford University and author of Golden Holocaust: Origins of the Cigarette Catastrophe and the Case for Abolition uses experiences with the digital tobacco archives to forecast how ToxicDocs can open a window onto a new and foreign world where a very powerful telescope will allow researchers to move from 'narrative reconstruction' (where documents are pieced together like a jigsaw puzzle), to a 
potentially democratizing force revealing crucial traces of corporate malevolence through new evidence of industries' motives, intent, and rhetorical strategies [6].

6. Elena N. Naumova, a mathematician and a nutrition and public health expert at Tufts University offers a Big Data perspective on ToxicDocs, including a new set of challenges - for consumers' data literacy to keep pace with data processing speed, to find substantial resources needed to maintain the database, and to protect the data from claims they are 'fake' [7].

7. Nicholas Freudenberg, a professor of public health in the US and author of Lethal but Legal: Corporations, Consumption, and Protecting Public Health, details the extensive efforts and tactics of corporations in shielding their harmful practices from scientific or public scrutiny. He places www.ToxicDocs. org within the emerging family of public sources of data and explains how investigative journalists are increasingly effective in exploiting them to unmask injurious industry strategies and how universities can use them to educate a new generation of professionals and researchers [8].

\section{References}

1. Rosner D, Markowitz G, Chowkwanyun M. ToxicDocs (www.ToxicDocs.org): from history buried in stacks of paper to open, searchable archives online. J Public Health Policy [special section] "ToxicDocs: Opening a new era of evidence for policies to protect public health" (Guest Eds. Rosner D, Markowitz G, Chowkwanyun M). 2018;39(1). https://doi.org/10.1057/s41271-017-0106-8.

2. Horel S. Browsing a corporation's mind. J Public Health Policy [special section] “ToxicDocs: Opening a new era of evidence for policies to protect public health" (Guest Eds. Rosner D, Markowitz G, Chowkwanyun M). 2018;39(1). https://doi.org/10.1057/s41271-017-0103-y.

3. Hogstedt C, Wegman D. ToxicDocs and the fight against biased public health science worldwide. J Public Health Policy [special section] "ToxicDocs: Opening a new era of evidence for policies to protect public health" (Guest Eds. Rosner D, Markowitz G, Chowkwanyun M). 2018;39(1). https://doi. org/10.1057/s41271-017-0104-X.

4. McCulloch J. Archival sources on asbestos and silicosis in Southern Africa and Australia. J Public Health Policy [special section] "ToxicDocs: Opening a new era of evidence for policies to protect public health" (Guest Eds. Rosner D, Markowitz G, Chowkwanyun M). 2018;39(1). https://doi.org/10. 1057/s41271-017-0110-z.

5. Whitehouse S. ToxicDocs: using the US legal system to confront industries' systematic counterattacks against public health. J Public Health Policy [special section] "ToxicDocs: Opening a new era of evidence for policies to protect public health" (Guest Eds. Rosner D, Markowitz G, Chowkwanyun M). 2018;39(1). https://doi.org/10.1057/s41271-017-0105-9.

6. Proctor RN. God is watching: history in the age of near-infinite digital archives. J Public Health Policy [special section] "ToxicDocs: Opening a new era of evidence for policies to protect public health" (Guest Eds. Rosner D, Markowitz G, Chowkwanyun M). 2018;39(1). https://doi.org/10.1057/s41271017-0111-y.

7. Naumova EN. The value of not being lost in our digital world. J Public Health Policy [special section] "ToxicDocs: Opening a new era of evidence for policies to protect public health" (Guest Eds. Rosner D, Markowitz G, Chowkwanyun M). 2018;39(1). https://doi.org/10.1057/s41271-017-0100-1.

8. Freudenberg N. ToxicDocs: a new resource for assessing the impact of corporate practices on health. J Public Health Policy [special section] "ToxicDocs: Opening a new era of evidence for policies to protect public health" (Guest Eds. Rosner D, Markowitz G, Chowkwanyun M). 2018;39(1). https://doi. org/10.1057/s41271-017-0101-0. 